\title{
A new paradigm of synergy between "Engineering Education" and "Fundamental Scientific Research"
}

\author{
C S Garde ${ }^{1}$ \\ ${ }^{1}$ Vishwakarma Institute of Information Technology, \\ S. No. 2/3/4, Kondhwa (Bk), Pune - 411048, India \\ 1'gardecs@gmail.com
}

\begin{abstract}
Engineering undergraduate students carry out a project in their final year. Many of these projects end up being mere study experiments which are never implemented in an industry or a research institute. We have identified the root causes for this failure and have developed a novel paradigm which has helped in carrying out projects in collaboration with Tata Institute of Fundamental Research (TIFR) which are subsequently deployed in an ongoing scientific experiment. Thus, TIFR gets state-of-the-art technology, faculty of our college, Vishwakarma Institute of Information Technology (VIIT), gets exposure to research laboratory and students learn, first hand, the nuances of technology development. It is thus a win-win situation for all the stake holders.
\end{abstract}

Keywords: Engineering Education, Undergraduate Projects, Fundamental Scientific Research, Collaboration, Technology Development, Human Resource Development

\section{S Garde ${ }^{1}$}

${ }^{1}$ Vishwakarma Institute of Information Technology, S. No. 2/3/4, Kondhwa (Bk), Pune - 411048, India 1'gardecs@gmail.com

\section{Introduction}

Development of cutting edge technology and its successful deployment is the key to growth of any country. India, in particular, can aspire to become a super power if and only if we can nurture precious human resource for achieving this. Kakodkar committees [1, 2] constituted by the Government of India for Indian Institute of Technology (IIT - report submitted in April 2011) and National Institute of Technology (NITs - June 2014) have made several recommendations for research oriented education system. The salient features of the observations and recommendations are:

IITs: Future lies in knowledge driven economy. Hence research should be an important component in education at IITs. IITs should aim at scaling the IIT system to 16,000 faculty and 160,000 total student strength (with 40,000, 40,000 and 80,000 at the $\mathrm{PhD}$, Postgraduate (PG) and Undergraduate (UG) levels, respectively) by around the year 2020. Each year, then, the IIT system will admit 10,000 PhDs and PGs each. IITs should tie up with premier Science and Technology institutes to attract the best students and faculty for their PhD programs.Attempt should be made to inspire third year undergraduate students to take up research as a career [1].

NITs: Some of the key areas that need to be recharged are high quality faculty, innovative research, excellent teaching, learning and evaluation methods, industry linkages, and institutional social responsibility. Moreover, the overriding aim of NITs must be to attract the brightest engineering talent in the country and shape them into excellent researchers or competent teachers. For that to happen, greater synergy must be developed with IITs and other reputed institutes [2].

The underlying theme is amalgamation of research and teaching in engineering institutes to generate technologically competent human resource as well as Research and Development (R\&D) infrastructure which will spur and sustain a long term industrial and economic growth of India. Taking a cue from these guidelines for IITs and NITs, other self funded and state funded engineering institutes should also start orienting their students towards R\&D and technology development.

\section{Problem}

The students of Engineering Undergraduate course (Bachelor of Engineering (BE)) under the Savitribai Phule Pune University (SPPU) have to carry out a project in the 
final year of their four year course. The project topics are obtained by the students from the industry or from the departments of the college. Due to several difficulties like lack of initiative, coordination and inadequate guidance, many of these projects are far from deployable.

\section{Novel Paradigm}

We have therefore developed a novel paradigm. Vishwakarma Institute of Information Technology (VIIT), Pune is a leading Undergraduate Engineering college in Pune. VIIT has a vision of imbibing the students with a zeal for innovation and excellence in their field of interest. Tata Institute of Fundamental Research (TIFR), Mumbai is a world renowned Research Institute. Research laboratories are always devising experiments for observing natural phenomenon with higher and higher precision and resolution for pushing the limits of knowledge. Cosmic Rays Laboratory (CRL) of TIFR situated at Ooty aims at studying cosmic ray showers created by high energy $\left(\sim 10^{15}-10^{17} \mathrm{eV}\right)$ charged particles (cosmic rays) coming from the outer space and is eminently lead by Prof (Dr) Sunil Gupta and Prof (Dr) Shashi Dugad. Prof. (Dr) S. Ramakrishnan from Department of Condensed Matter Physics and Material Science (DCMPMS) works in the field of Magnetism and Superconductivity at Micro-Kelvin temperatures. Prof. (Dr) S. S. Prabhu and Prof. (Dr) A. V. Gopal are engaged in research on Opto-electronics and Plasmonics, which could lead to futuristic technologies. These laboratories require development of high end instrumentation and software for data collection and analysis. VIIT, with 190 dedicated faculty and 600 final year (BE) students, is ideally suited to take up this challenge.

\subsection{Modus Operandi}

The modus operandi of the collaboration is as follows:

a) Students of third year (TE) are interviewed meticulously and their inclination towards independent thinking, urge to excel as an engineer and moral integrity are judged.

b) The selected students are sent to CRL, Ooty/ TIFR, Mumbai for summer internship for 2-3 weeks. Faculty members of VIIT also visit for a week.

c) The students interact with the researchers to understand the ongoing experiments and suggest possible projects they would like to take up.

d) After due approval, the final year (BE) projects are taken up by the students.

e) The most important aspect of this paradigm is that the responsibility of the project lies jointly with the VIIT and TIFR faculty and not the students. The faculty i) understands the project, ii) determines the skill sets required for the project, iii) finds out the initial skill set of the students and hence the gap between the skill set of the student and that required by the project and iv) devises a training strategy to fill this gap.

f) The students work on the project at VIIT under the guidance of faculty of VIIT. A separate laboratory has been established with state-of-the-art instruments for carrying out the TIFR projects. The laboratory is open for students even after college hours.
g)Strong interaction with scientists and engineers of TIFR through email, teleconferencing, etc is an important exercise to optimize the pace and direction of the project. h)Students regularly visit CRL, Ooty/ TIFR, Mumbai in each semester.

i)At the end, the students submit their hardware/ software to TIFR which is tested rigorously in the running experiments.

j) Since the projects are oriented towards developing the basic building blocks of larger devices, these blocks are used by TIFR to adapt the developed technologies in several different contexts in their experiments.

k)Many of these students, who have taken leading role in executing the project joins TIFR as Junior Research Fellow depending on availability of positions and implement the project in the scientific experiment.

1)Next year, the selected students from TE start working with the previous year students which ensure continuity in work.

\subsection{Growth of Collaboration}

Collaboration between VIIT and TIFR started with one project and two students in the year 2009-10 from the Department of Electronics and Telecommunication (E\&TC). Departments of Computer Engineering (Comp) and Information Technology (IT) joined this collaboration in 2011-12 and 2012-13, respectively. The collaboration has blossomed over the years as indicated by the table I.

\subsection{Beyond TIFR}

The success of VIIT-TIFR projects lead us to collaborating with other institutes like Indian Institute of Astro-Physics (IIA), Bengaluru in the year 2014-15 (Table II). In the Academic Year 2015-16, collaboration was extended to several Research Institutes other than TIFR (Table III).

\section{Benefits}

\subsection{From VIIT perspective}

Our experience has been very exhilarating. The students learn the following:

a) Defining a technical problem precisely

b) Plan a course of action

c) Execute the planned activities

d) Review the results and re-plan

e) Deploy and test the product in live experiment

f) Give seminars/presentations thus developing oral communication skills

g) Write reports thus developing writing skills

h) Interact with teachers, scientists and peers thus developing skills to work in a team

i) The students thus develop overall technical as well as soft skills. Further, the technical know-howdeveloped in a project is used as the base for the next year's BE project and hence the knowledge base is established and enhanced in the college which is directly used in TIFR laboratories. The foundation for long-term collaboration has thus been laid.

The immediate benefits of this collaboration are:

a) Research papers have been presented in International Conferences. 
b)Two students have received "National Photonics Fellowship". Out of these, one has completed MS and one is pursuing MS.

c)Several students have gone abroad to pursue $\mathrm{MS}$ and $\mathrm{PhD}$ in their fields of interest.

d)Recruiters from companies give preference to students who have done TIFR projects during their on-campus placement activity.
e)Several students have joined TIFR and have worked and/or are working on several research projects (Table IV). Apart from this, the faculties get enriched as they are closely involved in development of technology thus making

Table I: Growth of collaboration

\begin{tabular}{|c|c|c|c|c|l|}
\hline Year & $\begin{array}{c}\text { No. of } \\
\text { projects }\end{array}$ & $\begin{array}{c}\text { No. of } \\
\text { students }\end{array}$ & $\begin{array}{c}\text { No. of faculty } \\
\text { (VIIT) }\end{array}$ & $\begin{array}{c}\text { No. of scientists/ } \\
\text { engineers (TIFR) }\end{array}$ & Department(VIIT) \\
\hline $2009-10$ & 1 & 2 & 1 & 1 & E\&TC \\
\hline $2010-11$ & 8 & 20 & 8 & 8 & E\&TC \\
\hline $2011-12$ & 8 & 28 & 9 & 9 & E\& TC, Comp \\
\hline $2012-13$ & 12 & 38 & 9 & 9 & E\& TC, Comp, IT \\
\hline $2013-14$ & 15 & 49 & 11 & 10 & E\& TC, Comp, IT \\
\hline $2014-15$ & 15 & 45 & 10 & 10 & E\&TC, Comp, IT \\
\hline $2015-16$ & 19 & 64 & 12 & & \\
\hline Total & 78 & 246 & & & \\
\hline
\end{tabular}

Table II: Projects with IIA, Bengaluru in 2014-15

\begin{tabular}{|c|c|c|c|c|c|}
\hline Year & $\begin{array}{c}\text { No. of } \\
\text { projects }\end{array}$ & $\begin{array}{c}\text { No. of } \\
\text { students }\end{array}$ & $\begin{array}{c}\text { No. of faculty } \\
\text { (VIIT) }\end{array}$ & $\begin{array}{c}\text { No. of scientists } \\
\text { (IIA) }\end{array}$ & Department(VIIT) \\
\hline $2014-15$ & $\begin{array}{c}2(1 \mathrm{BE}, 1 \\
\text { ME) }\end{array}$ & 4 & 2 & 1 & E\&TC \\
\hline
\end{tabular}

Table III: Collaboration with Institutes other than TIFR in 2015-16

\begin{tabular}{|c|c|c|c|c|l|}
\hline Institute & $\begin{array}{l}\text { No. of } \\
\text { projects }\end{array}$ & $\begin{array}{l}\text { No. of } \\
\text { students }\end{array}$ & $\begin{array}{l}\text { No. of faculty } \\
\text { (VIIT) }\end{array}$ & $\begin{array}{l}\text { No. of scientists/ } \\
\text { engineers }\end{array}$ & Departments (VIIT) \\
\hline IIA, Bengaluru & 2 & 4 & 1 & 1 & E\&TC \\
\hline IISER, Pune & 1 & 3 & 1 & 1 & E\&TC \\
\hline SPPU, Pune & 3 & 7 & 2 & 1 & Comp \\
\hline IUCAA, Pune & 1 & 4 & 1 & & \\
\hline Total & 6 & 18 & & & \\
\hline
\end{tabular}

them more competent for teaching based on the solid foundation of R\&D.

\subsection{From TIFR perspective}

Several new technologies developed in collaboration with VIIT have been deployed successfully in scientific experiments of TIFR. Few examples are enlisted below:

1) Field Programmable Gate Array (FPGA) and Microcontroller based 32-channel scalar developed by VIIT students has now been modified and is being used for 60channel data acquisition (DAQ) card to measure count rate and pulse width of signal coming from Scintillator detectors as well as proportional counters. It is also used to upgrade existing slow PCI based DAQ to USB protocol on a LINUX operating system. As the card is quite generic, it is used as a general purpose FPGA development board.
2) Monitoring of High voltage $(2500 \mathrm{~V}$ dc) with a resolution of less than a volt for multiple channels (18 in the prototype) which can transfer data through USB was developed by our students. Multiple boards with I2C capability is now being used in CRL for monitoring close to 400 channels.

3) Solar Photovoltaic (PV) power system $(3 \mathrm{~kW})$ has being developed by VIIT. Such a system with enhanced capability will be installed at CRL

4) A 16-channel programmable power supply has been developed for Silicon Photo Multiplier (SiPM) with a capability of compensating for the temperature variation and keeping the variation in the gain of the SiPM to less than $0.5 \%$ over a temperature range of $15^{\circ} \mathrm{C}$. The cost per channel is Rs 500/- only. There is no equivalent instrument is available in the world, leave alone at such a low cost! 
5) After graduating from VIIT, some of the students have joined TIFR and are now working on development of instrumentation for CMS experiment at CERN, Geneva, Switzerland. They have designed and developed a DAQ for control, measurement and monitoring of neutron radiation for CMS detector. It is mounted in DAQ crate at P5 in CERN and is running without any glitch for several months now. They have also developed a high precision optical scanner with a beam width of $1.7 \mu \mathrm{m}$ for characterizing inter- as well as intra- pixel gain of a Silicon Photo Multiplier (SiPM).

6) VIIT students have also developed a web based comprehensive data management system for 400 scintillator counters using $\sim 100$ components for CRL. It keeps track of purchase, Quality Control, failure/ repair/ replacement history of each component in each scintillator

Table IV: Students in TIFR and beyond

\begin{tabular}{|c|c|c|c|c|c|}
\hline $\begin{array}{l}\text { Sr. } \\
\text { No }\end{array}$ & $\begin{array}{c}\text { Name of student } \\
\text { (BE Batch) }\end{array}$ & Project at TIFR & Post & $\begin{array}{l}\text { Lab at } \\
\text { TIFR }\end{array}$ & Present \\
\hline 1 & $\begin{array}{l}\text { SanketKamathe } \\
(2010)\end{array}$ & $\begin{array}{l}\text { Silicon Photo } \\
\text { Multiplier } \\
\text { (SiPM) }\end{array}$ & $\begin{array}{l}\text { Jr. Research } \\
\text { Fellow }\end{array}$ & \multirow[t]{6}{*}{$\begin{array}{l}\text { Solid State } \\
\text { Electronics, } \\
\text { Mumbai }\end{array}$} & $\begin{array}{l}\text { MS-TU Darmstadt } \\
\text { PhD(Pursuing) - } \\
\text { Imperial College, London }\end{array}$ \\
\hline 2 & $\begin{array}{l}\text { AmeyaDeshpande } \\
(2010)\end{array}$ & $\begin{array}{l}\text { Tera Hertz } \\
\text { Spectroscopy }\end{array}$ & $\begin{array}{l}\text { Jr. Research } \\
\text { Fellow }\end{array}$ & & $\begin{array}{l}\text { MS - North Carolina } \\
\text { State Univ, US }\end{array}$ \\
\hline 3 & Raj Patil (2011) & $\begin{array}{l}\text { Plasmonics } \\
\text { NRIM }\end{array}$ & $\begin{array}{l}\text { National } \\
\text { Photonics } \\
\text { Fellowship }\end{array}$ & & $\begin{array}{l}\text { MS (pursuing)- Univ. of } \\
\text { Arizona, US }\end{array}$ \\
\hline 4 & AniketPatil (2011) & $\begin{array}{l}\text { Plasmonic } \\
\text { Interconnects }\end{array}$ & $\begin{array}{l}\text { National } \\
\text { Photonics } \\
\text { Fellowship }\end{array}$ & & $\begin{array}{l}\text { MS Univ. of Central } \\
\text { Florida, US }\end{array}$ \\
\hline 5 & HarshadSurdi (2012) & $\begin{array}{l}\text { Tera Hertz } \\
\text { Spectroscopy }\end{array}$ & $\begin{array}{l}\text { Jr. Research } \\
\text { Fellow }\end{array}$ & & Arizona State Univ. US \\
\hline 6 & $\begin{array}{l}\text { PrathmeshDeshmukh } \\
\text { (2014) }\end{array}$ & THz, Plasmonics & $\begin{array}{l}\text { Jr. Research } \\
\text { Fellow }\end{array}$ & & At TIFR \\
\hline 7 & $\begin{array}{l}\text { RaghunandanShukla } \\
\text { (2011) }\end{array}$ & $\begin{array}{l}\text { SiPM, VLSI, } \\
\text { Embedded }\end{array}$ & $\begin{array}{l}\text { Scientific } \\
\text { Officer }(\mathrm{C})\end{array}$ & \multirow{3}{*}{$\begin{array}{l}\text { High } \\
\text { Energy } \\
\text { Physics, } \\
\text { Mumbai }\end{array}$} & At TIFR \\
\hline 8 & $\begin{array}{l}\text { SarrahLokahandwala } \\
\text { (2013) }\end{array}$ & $\begin{array}{l}\text { FPGA based } \\
\text { systems, SiPM }\end{array}$ & $\begin{array}{l}\text { Jr. Research } \\
\text { Fellow }\end{array}$ & & $\begin{array}{l}\text { University of Edinburgh, } \\
\text { UK }\end{array}$ \\
\hline 9 & AkhilKurup (2014) & $\begin{array}{l}\text { FPGA based } \\
\text { systems, SiPM }\end{array}$ & $\begin{array}{l}\text { Jr. Research } \\
\text { Fellow }\end{array}$ & & At TIFR \\
\hline 10 & SurajKolhe (2012) & VLSI, Embedded & $\begin{array}{l}\text { Jr. Research } \\
\text { Fellow }\end{array}$ & \multirow{5}{*}{$\begin{array}{l}\text { Cosmic } \\
\text { Rays } \\
\text { Laboratory, } \\
\text { Ooty }\end{array}$} & M Tech, CoEP, Pune \\
\hline 11 & Serin V. John (2013) & $\begin{array}{l}\text { High voltage } \\
\text { DAS, Embedded }\end{array}$ & $\begin{array}{l}\text { Jr. Research } \\
\text { Fellow }\end{array}$ & & $\begin{array}{l}\text { MS (admitted) - TU } \\
\text { Chemnitz, Germany }\end{array}$ \\
\hline 12 & $\begin{array}{l}\text { AkshayManjare } \\
\text { (2014) }\end{array}$ & $\begin{array}{l}\text { Embedded, } \\
\text { Instrumentation }\end{array}$ & $\begin{array}{l}\text { Jr. Research } \\
\text { Fellow }\end{array}$ & & At TIFR \\
\hline 13 & $\begin{array}{l}\text { PankajRakshe BE } \\
(2011), \text { ME (2014) }\end{array}$ & $\begin{array}{l}\text { Embedded, } \\
\text { Instrumentation }\end{array}$ & $\begin{array}{l}\text { Scientific } \\
\text { Officer (D) }\end{array}$ & & At TIFR \\
\hline 14 & ShubhamNegi (2015) & $\begin{array}{l}\text { Solar PV, } \\
\text { Instrumentation }\end{array}$ & $\begin{array}{l}\text { Jr. Research } \\
\text { Fellow }\end{array}$ & & At TIFR \\
\hline 15 & Sameer Saraf (2013) & Embedded & $\begin{array}{l}\text { Project } \\
\text { Engineer }\end{array}$ & $\begin{array}{l}\text { Atomic } \\
\text { Physics } \\
\text { Laboratory, } \\
\text { Mumbai }\end{array}$ & $\begin{array}{l}\text { MS (admitted) - } \\
\text { Michigan Tech. Univ, US }\end{array}$ \\
\hline
\end{tabular}

and creates analysis reports and alerts which help in keeping the system up and running $24 \times 7$.

7) ERP system manufacturing proportional counters has been developed for CRL. The manufacturing involves manufacturing from $6 \mathrm{~m} \times 0.1 \mathrm{~m} \times 0.1 \mathrm{~m}$ MS tubes, stretching 100 micron tungsten wire, vacuum sealing, Argon filling and testing. The ERP system will also be used to deploy and monitor the proportional counters in the experiment.

8) Web based software has been developed for CRL for analysis of data and will dynamically generate plots through remote access by collaborators from anywhere in the world.
9) There are several power electronics projects in the pipeline.

\section{Memorandum of Understanding with TIFR}

As a result of the dynamic collaboration between the two institutes, VIIT and TIFR have signed a Memorandum of Understanding (MOU) for working together in the field of Research and Education. Prof S K Gupta and Prof C S Garde are the coordinators from TIFR and VIIT, respectively.

\section{Conclusion}

A novel paradigm has been developed where close collaboration between faculty and engineers from a college 
and a research institute helps to train students in development of technologies which are ultimately deployed in the laboratory of the research institute. It is thus a winwin situation for all the stake holders, i.e. students and faculty of the college and laboratories of the research institute.

\section{Acknowledgements}

I would like to acknowledge the dedicated efforts of all the faculty and engineers of TIFR, VIIT and students of VIIT who contributed to the success of this collaboration.

\section{References}

[1] Anil, Kakodkar et al, Taking IITs to excellence and greater relevance: Report of Dr Anil Kakodkar Committee April 2011

[2] Anil Kakodkar et al, NITs as drivers for higher technical education - the way forward: Kakodkar Committee Report June2014 